\title{
The Role of Chief-King Among the Akan: A Theological Reflection
}

\author{
Anthony Kofi Anomah¹, Peter Addai-Mensah² \\ 1 Spiritan University College, Ejisu Ashanti, Ghana \\ ${ }^{2}$ Department of Religious Studies, Kwame Nkrumah University of Science and Technology ,Ghana.
}

\begin{abstract}
The study seeks to explore the role of chiefs-kings among the Akan in Ghana vis-à-vis the functions of the District/Municipal and Metropolitan Assemblies and the relevance of the chieftaincy institution in contemporary society. A literary approach was adopted for the study making use of analysed secondary data. The study findings indicated that whereas the functions of the District/Municipal and Metropolitan Assemblies are political and administrative, that of the chiefs-kings among the Akan in Ghana are executive, legislative, judicial, religious (spiritual) and agents of development. The functions of the Assemblies are therefore complementary, collaborative and co-operative to that of the chiefs-kings. Thus, the District/Municipal and Metropolitan Assemblies and the chieftaincy institutions are not opposed to each other but collaborative in function. The article maintains that the chieftaincy institution is still relevant in contemporary society despite the abuses by some chiefs-kings and cannot be replaced by the District/Municipal and Metropolitan Assemblies.The study recommends that the District/Municipal and Metropolitan Assemblies and the chiefs-kings should recognise each other as partners and collaborators in their jurisdictions and not as competitors or opponents. The Assemblies should recognize that the chiefs-kings are the custodians of the land and intermediaries between the living and the ancestors and give them their due rights. As such, the chiefs-kings hold the keys to the peace and development of their kingdoms; and chiefs-kings should serve their subjects as role models and govern them with humility, justice and peace. The study contributes to the understanding of the chieftaincy institution among the Akan in Ghana.
\end{abstract}

Keywords: Chieftaincy institution, Chiefs-Kings, development, selection.

Correspondence:

Anthony Kofi Anomah

Email: anomah13@gmail.com

Manuscript

Received 15th July, 2020,

Accepted 21st August 2020,

Published online 31st August 2020.

\section{INTRODUCTION}

According to Marfo and Halidu, the chiefs were the leaders, law-makers and judges of their jurisdictions. ${ }^{2}$ However, in contemporary society such as Ghana, many of the roles that used to be played by chiefs have been given to state agencies such as the District/Municipal/Metropolitan Assemblies. ${ }^{3}$ However, they are also of the view that the chieftaincy institution is still relevant in contemporary society despite some of its flaws. This is because, in some areas, people rely solely on chiefs for conflict resolution and peaceful settlement of their disputes. ${ }^{4} \mathrm{~A}$ case in point is the settlement of the protracted chieftaincy dispute in Dagbon (Northern-East Region, Ghana) by the Eminent Chiefs led by Otumfuo Osei Tutu II, commissioned by His Excellency, Nana Addo Danquah Akuffo Addo. Chiefs serve as Alternative Dispute Resolution mediators. They assist parties involved in disputes or negotiations to achieve mutually acceptable resolution of cases, being they chieftaincy, land, property, or marriage disputes. In the view of Nweke, chiefs are people with good moral standing who are selected and installed in line with traditional customs and laws. ${ }^{5}$ According to Marfo and Halidu,

\footnotetext{
Samuel Marfo and Musah Halidu, "Examining the Position of the Chieftaincy Institution in Modern Political Systems of Ghana" Journal of Sociology and Social Work. 6, No. 1, (2018), 64-72

Ibid.

Ibid.

K. Nweke, The Role of Traditional Institutions of Governance in Managing Social Conflicts in Nigeria’s Oil-Rich Niger Delta Communities: Imperatives of Peace-Building Process in the Post-Amnesty Era. British Journal of Arts and Social Sciences, 5 No. 2 (2012).
} 
chiefs were the custodians of unity, peace and security in their kingdoms. ${ }^{6}$

Nowadays, chiefs are deeply involved in the socio-economic development of their jurisdictions. Many of them have made significant contributions in terms of development, education, environmental protection and the safety of the people. For example, in the Asante kingdom, the Asantehene, Otumfuo Osei Tutu II has established the Otumfuo Educational Fund for the promotion of education in Asanteman and Ghana as a whole. ${ }^{7}$ Similarly, the Okyenhene, Osagyefo Amoatia Ofori Panin, has shown consistent commitment to address some of the environmental challenges confronting the Akyem Abuakwa Traditional Area. ${ }^{8}$

The chieftaincy institution is a cultural heritage. Chiefs are selected as the leaders of their communities to govern and protect the people against external aggressors and to ensure peace and security for their subjects. They are the intermediaries between the living and the ancestors who live in the spiritual realm. In the past, chiefs exercised executive, legislative, judicial and religious functions. They commanded a great deal of respect, independence and authority. However, in contemporary societies, this is not the case. Over the years, the role of the chiefs in Ghana is gradually being replaced by the District/Municipal and Metropolitan Assemblies. The chiefs no longer control the revenues of their territories as they used to do. In effect, access to local taxation and revenues are now under the management of local District/Municipal/Metropolitan Assemblies. This situation has greatly affected their role as development agents. While some chiefs continue to wield power and influence in their communities in terms of development, others have become agents of conflict and land disputes, and exploit their subjects for personal gains. The study therefore seeks to explore the role of chiefs-kings among the Akan in Ghana vis-à-vis the functions of the District/Municipal and Metropolitan Assemblies and the relevance of the chieftaincy institution in contemporary society.

\section{METHODOLOGY}

The literary approach was used for the study. Secondary data from library sources and the Internet were analysed and used in the study.

\section{The Constitution of the Republic of Ghana on the Chieftaincy Institution}

The 1992 Constitution of the Republic of Ghana defines a chief as a person who hails from the appropriate family and lineage, has been validly nominated, elected or selected and enstooled, enskinned or installed as a chief or queen mother in accordance with the relevant customary law and usage. ${ }^{9}$ For the purpose of this article, the title "chief" and "king" will be used interchangeably.

\section{The Selection and Enstoolment of Asante King or Chief}

In the Asante Kingdom, a King's position becomes vacant on account of death, abdication or destoolment. It is the duty of the Kurontihene (second in command to the king) to make a request to the queen for a candidate to be enstooled as king. The queen summons the lineage to a meeting to consider the candidature of those who are eligible to occupy the stool. A nominee is then presented to the public who have the right to approve or reject the candidate. If he is rejected, another nominee is proposed until one is accepted by the public. Then the king-elect is installed. The new King is advised by the elders not to become a womaniser, drunkard, gambler, miser, autocrat, abuser or bully. Instead, he should listen to advice and keep confidentiality. The king is expected to be intelligent, humble, physically fit, honest, patient, selfcontrolled, respectful, brave and generous. ${ }^{10}$

The king is responsible for the administration and running or management of affairs of the kingdom. He could be destooled if he neglects his duties or people lose confidence in him. The king is also the intermediary between the living, the ancestors and those yet unborn. The Asantes believe that the prosperity and wellbeing of the people depend upon the healthy relationship which exists between the living and the ancestors. ${ }^{11}$ They also believe "that the ancestors provide the living with their material and physical needs and protect them from misfortune." ${ }^{2}$ According to Effa Ababio, "the living are expected to reciprocate the ancestral protection, blessing and goodwill by veneration through sacrifices and living in peace and harmony with one another."13

The chief-king is the intermediary between the living and the ancestors. The Akans in general venerate their Marfo and Halidu, "Examining the Position of the Chieftaincy Institution", 64-72

7 Seidu Hafis-Deen. "An Examination of Chieftaincy Institution: The Role and Challenges of Chiefs in the Socio-economic Development of the Dorimon Traditional Area of the Upper West Region of Ghana." M. Phil Thesis submitted to the University for Development Studies, May 2016.

8 Charles Andoh, "Okyenhene supports Atiwa Forest Project" Graphic Online, 29 ${ }^{\text {th }}$ April 2015. Accessed July 9, 2020.

1992 Constitution of the Republic of Ghana (Accra: Ministry of Justice/Allshore Co. 2005).

Kofi Effa Ababio, The Church and Traditional Rule: Church-Traditional State Relations (Accra: Adwinsa Publication (Gh) Ltd.), 2015$), 68$.

1 Ibid., 72 .

2 Ibid.

13 Ibid. 
ancestors and believe that the ancestors are in the position to intervene in the lives of their living descendants for good or evil. Therefore, the chief-king makes periodic sacrifices to these spirits on behalf of family members. The chief-king communes with the ancestral spirits for the benefit of the family, town, or confederation. The king performs ceremonies and sacrifices to the ancestors on important occasions such as festivals marked by dramatic drumming, dancing, and pageantry. ${ }^{14}$

\section{The Key Functions of a Chief-King Among the Akans}

In Rattray's opinion, the duties of a chief are strictly defined on the occasion of his enstoolment. The chief is urged not to disclose the origin of any person; not to curse anyone, not to be greedy. He should listen and seek advice from the elders. He should not insult his elders; rather he should have time for them and not to abuse them. He should not be violent. ${ }^{15}$

Moreover, the chief is the commander of the army. The chief and elders are responsible for the administration of the battalion. They perform the necessary sacrifices for the welfare of the people. They are responsible for seeing to it that law and order are maintained and that the customs are followed. ${ }^{16}$ Similarly, it is the duty of the chief to consult the elders on all matters, and to obey their advice. ${ }^{17}$ The chief "therefore had to reconcile the sectional interests of the elders." 18 Busia admonishes chiefs to use their wealth at the service of others and not to accumulate wealth for their personal use. ${ }^{19}$

Mbiti observes that not all Africans have traditional rulers in the form of kings, queens or chiefs. ${ }^{20}$ However, wherever they are found, they are the religious heads and promoters of the wellbeing of the people. They are the intermediaries between the living and the spirits. Thus, they are highly regarded and are sometimes given titles such as 'saviour,' 'protector,' 'child of God,' 'chief of the divinities,' 'lord of earth and life.2. ${ }^{21}$ As a result, there are myths, taboos and superstitions surrounding the origin of kings. ${ }^{22}$ Similarly, kings are sometimes seen as extraordinary people. For instance, the king must not touch the ground with his feet, and has either to be carried or walk on a special mat; and to protect him, certain rituals and sacrifices have to be performed; he is to wear amulets and consult diviners for protection against his foes. ${ }^{23}$

Mbiti observes that in some places kings serve as priests, rainmakers, intermediaries, diviners or mediators between humanity and God. ${ }^{24}$ Similarly, kings are considered to be holy, and must be respected, honoured and revered. ${ }^{25}$ Thus, the wellbeing of the king is of high esteem because his demise is a national disaster. No wonder, the demise of a chief brings a complete disruption to life, and only a new ruler would both restore order and symbolise normality once more. ${ }^{26}$

According to Michael Cobb, chiefs are administrative, cultural, judicial, military, spiritual and agents of development in their jurisdictions. They serve as rulers of their communities and symbols of culture and heritage. They settle disputes among their subjects and lead their people against external aggressors. They also champion development projects in their areas of jurisdiction. Spiritually, they are the intermediaries between the gods, the spirits and the ancestors, and intercede for the wellbeing of their people. ${ }^{27}$

\section{Religious and Political Leader}

A chief-king is an executive, legislative, judicial, military, economic and religious leader of his subjects. He mobilizes his subjects in times of trouble in order to defend his subjects and to protect his territory. Even though the chief does not have to go to war nowadays people look up to him for religious, economic, political and social leadership. He creates the needed ambience for socio-economic development. He champions educational, health and infrastructural development in order to fight poverty, illiteracy and disease within his traditional area. ${ }^{28}$ According to Awuah-Nyamekye, chiefs

\footnotetext{
14 Brian Schwimmer, Department of Anthropology, University of Manitoba, 2001. Accessed July 9, 2020.

15 R. S. Rattray, Ashanti Law and Constitution. (Oxford: Clarendon Press, 1929/1969), 81- 82.

${ }_{16}$ K. A. Busia, The Position of the Chief in the Modern Political System of Ashanti: A Study of the Influence of Contemporary Social Changes of Ashanti Political Institutions. (London: Frank Cass \& Co., 1968), 14.

17 Ibid.

18 Ibid.

19 Ibid., 82.

20 John S. Mbiti, African Religions and Philosophy, $2^{\text {nd }}$ ed. (Ibadan: Heinemann Educational Books (Nigeria) Ltd., 1989$), 177$.

Ibid., 178.

22 Ibid.

23 Ibid.

24 Ibid.

25 Ibid.

26 Ibid., 179

27 Michael Cobb "Chieftaincy and the Civil State: Relations between Traditional and Modern Leadership and a look at Chieftaincy Conflicts in Ghana”.

28 Irene K. Odotei and Albert K. Awedoba, Chieftaincy in Ghana: Culture, Governance and Development (Accra: Sub-Saharan Publishers, 2006),11.
} 
mobilise their people for communal labour for the development of their traditional areas. Thus, in areas where there are no chiefs, developmental projects come to a standstill. ${ }^{29}$

The chief-king is both the political and the religious representative of his area. He officiates at libation prayer for himself and his subjects. According to Tweneboah, the chief is the political leader of the Akan group. He is the link between the ancestors and the living and mediates for the welfare of the community. ${ }^{30}$

The chief enters the stool room to pour libation on sacred days to ask for blessings from the ancestors. As a religious leader, it is the legitimate responsibility of the chief to perform this rite failure of which could lead to his destoolment in the Akan society. The chief is the official representative of the ancestors in the traditional area. ${ }^{31}$ Thus, in the opinion of Awuah-Nyamekye, the king's divine mediatorship enables him to perform the necessary rituals capable of sustaining and protecting society from disaster. ${ }^{32}$

\section{Intermediary between the Living and the spirits (gods and ancestors)}

According to Tweneboah, the chief is the intermediary between the living and the ancestors, the link person between the departed ancestors and their living relatives and the intercessor for the living. ${ }^{33}$ In the same way, Awuah-Nyamekye sees the chief as the right person to represent the living at the court of the ancestors and solicits for blessings from the ancestors on the people. ${ }^{34}$ Thus, in his view, the blood relations between the chief and the ancestors gives the former a legitimate right over all other spiritual personalities in his jurisdiction to solicit for the blessing of the ancestors on behalf of his people.

\section{Symbol of Culture and Heritage of the People}

The chief is the custodian of the rich culture of the Akan people. He champions and lobbies for development projects in his area, however, in some societies today, one often hears of some chiefs-kings who use their positions to amass wealth and enrich themselves instead of looking for the wellbeing of their subjects. This behaviour of the latter undermines the very nature and role of the chieftaincy institution in Akan society and culture.

\section{The Local Government Act, 1993, ACT 462}

The Local Government Act, 1993, Act 462 of the Republic of Ghana was "established to regulate the local government system in accordance with the Constitution of Ghana and to provide for related matters." 35 The Assemblies exercise political and administrative authority and supervise the overall development of the District/Municipal and Metropolitan Assemblies. ${ }^{36}$ They co-operate with the appropriate national and local security agencies, public corporations, statutory bodies or non-governmental organisations in the maintenance of security and public safety in the district. ${ }^{37}$ It is also the responsibility of the assemblies to "give direction to, and supervise the other administrative authorities in the district," 38 "formulate and execute plans, programs and strategies for the effective mobilisation of the resources necessary for the overall development of the district;" ${ }^{39}$ and "initiate programs for the development of basic infrastructure, provide municipal works and services and promote justice in the district. ${ }^{40}$ From the foregoing, it is clear that the District/ Municipal and Metropolitan Assemblies perform some of the functions of the chiefs-kings in their traditional areas and so cannot replace them. Thus, it is appropriate that the assemblies work in collaboration with the chiefs-kings of their jurisdictions.

\section{A THEOLOGICAL REFLECTION}

In this section, the writers reflect theologically on the responsibilities of kings regarding the Christian Bible, the role of chiefs-kings among the Akan of Ghana and the relevance of chiefs-kings today in their traditional areas and on their subjects.

\footnotetext{
29 Samuel Awuah-Nyamekye, "The Role of Religion in the Institution of Chieftaincy: The Case Study of the Akan of Ghana”. Lumina Vol. 20, No. 2, May 2014, 9.

30 Seth Tweneboah, The Sacred Nature of the Akan Chief and its Implications for Tradition, Modernity and Religious Human Rights in Ghana, (MA Thesis Submitted to Florida International University, 2012), 87-89.

31 Awuah-Nyamekye, The Role of Religion in the Institution of Chieftaincy, 7.

32 Ibid.

33 Tweneboah, The Sacred Nature of the Akan Chief, 87-89

34 Awuah-Nyamekye, The Role of Religion in the Institution of Chieftaincy, 7.

35 The Local Government Act 1993, Act 462

${ }^{36}$ Ibid.

37 Ibid.

38 Ibid.

39 Ibid.

40 Ibid.
} 


\section{The King in the Old Testament}

Unlike the other nations, the Israelites had no king until they requested for a King from Samuel ${ }^{41}$ Until this time, the Israelites recognised God as their King. God ruled over them through God's appointed people such as Moses, Joshua, and the Judges. God was the Shepherd of Israel. ${ }^{42}$

There are two major divergent opinions regarding the request for a king. One school of thought (antimonarchical) believes that the demand for a king meant Israel's rejection of God's kingship over them. However, another school of thought (pro-monarchical) believes that it was Samuel who took the initiative and appointed Saul as the first king of Israel. ${ }^{43}$

The monarchical form of government continued from the time of Saul until the appointment of David as king of Israel. During this period of kingship, the prophets served as checks and balances of the kings. The prophets supported the kings during their reign but also criticised them when they went contrary to the precepts of the Lord. For example, Nathan criticised David for the role he played in the death of Uriah. ${ }^{44}$

\section{The Kingship of Jesus Christ}

In the Roman Empire there were kings but only the king of Rome was called King of kings. Therefore, to call Jesus not just a king but the King of Kings was in opposition to the Roman Emperor. Yet the writer of the Book of Revelation describes Jesus as the "Lord of lords and the King of kings;" 45 and elsewhere praises Jesus as "the Lamb of God", "Lord God Almighty"; and as "King of nations." ${ }^{46}$

During the trial of Jesus, Pilate asked Jesus whether he was a king and Jesus replied, "Mine is not a kingdom of this world; if my kingdom were of this world, my men would have fought to prevent my being surrendered to the Jews. As it is, my kingdom does not belong here." ${ }^{47}$ Again, when Pilate said, 'so, then you are a king? Jesus answered, "It is you who say I am a king."48 The inscriptions Pilate wrote and fixed on Jesus' cross read: "Jesus the Nazarene, King of the Jews." ${ }^{49}$

However, it must be pointed out here that the kingdom or kingship of Jesus being referred to is an eschatological kingdom or kingship, quite different from the earthly kingdoms and kingships of the Akan. In His instructions to his disciples and apostles, Jesus urged them to be servant leaders and serve their subjects instead of waiting to be served by the subjects. Jesus was an example to the disciples in humility and service even to the point of giving Himself up as a ransom for many ${ }^{50}$ It is believed that the king or chief is called by God to serve as a leader. Effa Ababio says, "the belief is that it is God who appoints the leader." ${ }^{\prime \prime}$

Jesus was and is King. However, His kingship is everlasting, eternal and conferred by God. St. Paul in his first letter to Timothy outlines the essential qualities of a leader. According to him, a leader must be irreproachable, monogamous, temperate, sensible, dignified, hospitable, an apt teacher, not alcoholic, not violent but gentle, not quarrelsome, and not lover of money. ${ }^{52}$ Similarly, St. Mark says, riches are held in trust and rich people are stewards of God's treasure and should use their riches to help others and are accountable to God for the way they use their riches. ${ }^{53}$

On the other hand, kings are selected by human beings and are entrusted with the care of material (lands, personnel, money, machines), and spiritual possessions. Like Christ, they exercise the three roles of kings, prophets and priests. As priests, they are intermediaries between humanity and the spirits (ancestors). They are intercessors and reconcilers, just as Christ intercedes for his people and reconciles them to Himself and to God, His Father. Chiefs-Kings are expected to offer themselves daily as sacrificial lambs for the good of their subjects. As prophets, they are role models, teachers and witnesses of truth and good conduct in their everyday family and social lives. Chiefs-Kings are also judges whose judgment must be just and without fear or favour. Lastly, as chiefs-kings, they are expected to govern their people with integrity, honesty, sincerity and justice. They are to order everything entrusted to their care to God according to the teachings of the gospel, in truth, charity, justice and peace.

\footnotetext{
1 Samuel 8:5.

42 Psalm 23:1.

431 Samuel 9:1-10:17 and 1 Samuel 8; 10:17-27. (cf. https://www.britannica.com/biography/Samuel-Hebrew-prophet\#ref56754).

442 Samuel 12:1-14

45 Revelation 17:13-14.

46 Revelation 15:3.

47 John 18:36

48 John 18:37.

49 John 19:19.

50 Matthew 20:26-27 (cf. Philippians 2:7-8).

51 Effa Ababio, The Church and Traditional Rule, 82.

1 Timothy 3:2-3.

3 Mark 10:17-41; Effa Ababio, The Church and Traditional Rule, 86.
} 


\section{The Relevance of the Chieftaincy Institution among the Akans Today}

From the above, several analogies can be drawn between the chiefs-kings of today who are performing their roles as priests, prophets and kings creditably as Jesus did, and those who are not. The former includes, the Asantehene Otumfuo Osei Tutu II, Okyehene Ofori Amoatia II, to name but a few. The two have made significant contributions to their kingdoms and Ghana as a whole and are worthy of emulation. Since he ascended the throne on $26^{\text {th }}$ April 1999, Otumfuo Osei Tutu II has initiated many developmental projects in the Asante Kingdom such as the Otumfuo Educational Fund. These developmental projects have earned him the accolade, "King Solomon," and the love and admiration of many people in and out of the kingdom. The authors agree with Aryee when he compares the chiefs-kings of yesteryears with the chiefs of contemporary society. Unlike the chiefs-kings of the past who engaged in inter-tribal wars and conquest over territories and people, the chiefs-kings of today aim at eliminating poverty, disease and ignorance. The chieftaincy institution is used for economic development, proper land management, socio-economic and infrastructural development such as school and hospitals, facilitating investments in local communities, and eliminating illegitimate chiefs who use their money and influence to ascend the throne and create unnecessary rivalry and chieftaincy disputes. ${ }^{54}$ The kingship of Otumfuo Osei Tutu II is like the one inaugurated by Jesus. It is not a kingdom of eating and drinking but of saving justice and peace in the Holy Spirit. ${ }^{55}$

In the past, many Christians shunned the chieftaincy institutions as un-Christian and had nothing to do with it. However, today the Church encourages especially the laity to be involved in social and political issues in their societies. They are called upon to influence the social environment with gospel values and participate in political activities. ${ }^{56}$ By their involvement in the chieftaincy institution and politics the laity apply the values of the gospel to concrete issues in society ${ }^{57}$ For example, some Catholic chiefs in the Archdiocese of Kumasi have taken up this challenge and are actively involved in the chieftaincy institution. These chiefs have organised themselves and formed the "Catholic Chiefs Association" in order to bring Christian principles to bear on the chieftaincy institution and to influence chieftaincy matters and decisions with gospel values. With the support of the Most Rev. Peter Kwasi Sarpong former Archbishop of Catholic Archdiocese of Kumasi, they are 'Christianising' some traditional rituals such as libation, widowhood rites and incorporating them into the Catholic liturgy in the Archdiocese of Kumasi.

However, there are exceptions to the rule. For example, according to Okyere Bonna, some chiefs have lost their spiritual and moral authority by involving themselves in dubious land sales ${ }^{58}$ For example, a correspondent of Starrfm. com.gh reported on Ghanaweb (an online news website) on $15^{\text {th }}$ May 2019 that the Asantehene, Otumfuo Osei Tutu II, had dissolved the Asante Hemaa's court because chiefs who sit on the court had been convicted of corruption. ${ }^{59}$ This is a case of corruption among some chiefs-kings, rulers and monarchs.

Similarly, some chiefs-kings use their positions to enrich themselves instead of looking for the welfare of their subjects. ${ }^{60}$ Furthermore, there are cases of incessant and protracted chieftaincy disputes in some areas such as Kumawu in the Ashanti Region which hampers development. ${ }^{61}$ Sometimes, there are disputes over land, the allocation of District, Municipal or Regional capitals. At other times, some chiefs-kings demand huge sums of money before they release lands for developmental projects. ${ }^{62}$ These and many others do not augur well for the chieftaincy institution and bring the noble institution into disrepute.

\section{RECOMMENDATIONS}

The study recommends that

1. the District/Municipal and Metropolitan Assemblies partner, complement, collaborate and co-operate with chiefs-kings in their traditional areas and not to compete or oppose each other in the administration of their jurisdictions.

2. the Assemblies recognize the chiefs-kings as the legitimate custodians of the land and intermediaries between the living and the ancestors and give them their due rights.

3. the District/Municipal and Metropolitan Assemblies appreciate the fact that the chiefs-kings hold the keys to

\footnotetext{
54 J. R. A. Ayee, "Traditional Leadership and Local Governance in Africa: The Ghanaian Experience”: Paper presented at the Fourth National Annual Local Government Conference on the theme "Traditional Leadership and Local Governance in a Democratic South Africa: Quo Vadis" held from 30-31 July 2007 at the Southern Sun - Elangeni, Durban. Accessed on July 9, 2020

55 Romans 14:17.

56 Robert M. Schwartz, Servant Leaders of the People of God. (New York: Paulist Press, 1989), 71.

57 Ibid.

58 Okyere Bonna, “The Role of Chieftaincy in Ghana”, Opinions of Wednesday, 26 $6^{\text {th }}$ April 2006. Accessed Monday 13th April 2020 at 11; 44 am.

59 Starrfm.com.gh, Wednesday May 15, 2019, Accessed April 13, 2020.

${ }_{60}$ Kwame Asamoah, "A qualitative study of chieftaincy and local governance in Ghana," Journal of African Studies and Development, 4, no. 3, (2012), 90-95. Accessed July 4, 2020.

${ }^{61}$ Ibid.

62 Asamoah, "A qualitative study of chieftaincy and local governance in Ghana," 93.
} 
the peace and development of their traditional areas and collaborate with them in developmental, security and peace initiatives.

4. chiefs-kings should serve their subjects as role models and govern them with humility, justice and peace.

\section{CONCLUSION}

In conclusion, this article has explored the selection, the enstoolment, the role and the relevance of chiefs-kings among the Akan of Ghana. It has also examined how the chiefs-kings govern and lead their subjects in development, freedom, unity, justice and peace in their traditional areas. Moreover, the text reflected on their roles as judges, priests and agents of development. The authors noted with delight that there are some model chiefs-kings in modern day Ghana who are worthy of emulations as well as some who are not. The study recommends that the District/Municipal and Metropolitan Assemblies should partner, complement, collaborate and co-operate with chiefs-kings in their traditional areas and not compete or oppose each other in the administration of their jurisdictions. In addition, the Assemblies should recognise chiefs-kings as the legitimate custodians of the land and intermediaries between the living and the ancestors and give them their due rights; and appreciate the fact that the chiefs-kings hold the keys to the peace and development of their traditional areas and collaborate with them in developmental, security and peace initiatives.Finally, chiefs-kings should serve their subjects as role models and govern them with humility, justice and humility and peace. Like Christ, chiefskings should be ready to lay down their lives for their subjects. ${ }^{63}$

\section{BIBLIOGRAPHY}

Ababio, Kofi Effa. The Church and Traditional Rule: Church-Traditional State Relations. Accra: Adwinsa Publication (Gh) Ltd.), 2015.

Andoh, Charles, "Okyenhene supports Atiwa Forest Project" Graphic Online, 29 $9^{\text {th }}$ April 2015. (Accessed July 9, 2020). Anomah, Anthony Kofi \& Addai-Mensah, Peter. An African Perspective on the Veneration of the Saints and the Ancestors, Journal of Philosophy, Culture and Religion, 45, (2019): 11-16 DOI:10.7176/JPCR/45-02.

Asamoah, Kwame, A qualitative study of chieftaincy and local governance in Ghana, Journal of African Studies and Development 4, no. 3, (2012): 90-95. (Accessed July 7, 2020).

Awuah-Nyamekye, Samuel. The Role of Religion in the Institution of Chieftaincy: The Case Study of the Akan of Ghana. Lumina, 20, No. 2, (2009).

Ayee, J.R.A “Traditional Leadership and Local Governance in Africa: The Ghanaian Experience": Paper presented at the Fourth National Annual Local Government Conference on the theme "Traditional Leadership and Local Governance in a Democratic South Africa: Quo Vadis" held from 30-31 July 2007 at the Southern Sun - Elangeni, Durban.

Brian Schwimmer, Department of Anthropology, University of Manitoba, 2001.

Busia, K. A. The Position of the Chief in the Modern Political System of Ashanti: A Study of the Influence of Contemporary Social Changes of Ashanti Political Institutions. London: Frank Cass \& Co., 1968.

1992 Constitution of the Republic of Ghana, Accra: Ministry of Justice/Allshore Co. 2005.

Mbiti, John A. African Religions and Philosophy, $2^{\text {nd }}$ ed. Ibadan: Heinemann Educational Books (Nigeria) Ltd., 1989.

Odotei, Irene K. \& Adedoba, Albert K. Chieftaincy in Ghana: Culture, Governance and Development. Accra: Sub-Saharan Publishers, 2006.

Okyere Bonna, “The Role of Chieftaincy in Ghana, Opinions of Wednesday, 26 $6^{\text {th }}$ April 2006.” Accessed April 13, 2020.

Rattray, R. S. Ashanti Law and Constitution. Oxford: Claredon Press, 1929/1969

Schwimmer, Brian. Department of Anthropology, University of Manitoba, 2001.

Schwartz, Robert M. Servant Leaders of the People of God. New York: Paulist Press, 1989.

The Local Government Act 1993, Act 462

Tweneboah, Seth. The Sacred Nature of the Akan Chief and its Implications for Tradition, Modernity and Religious Human Rights in Ghana, MA Thesis Submitted to Florida International University, 2012.

63 John 15:13. 


\begin{abstract}
ABOUT AUTHORS
Anthony Kofi Anomah is a Catholic priest of the Congregation of the Holy Spirit (Spiritans), Province of Ghana. He is the Rector of the Spiritan University College, Ejisu Ashanti, Ghana. His research interests are Christianity and culture, inter-religious dialogue and inculturation.
\end{abstract}

Peter Addai-Mensah(STD) is a Catholic priest of the Archdiocese of Kumasi and a Senior Lecturer at the Department of Religious Studies, Kwame Nkrumah University of Science and Technology, (KNUST), Kumasi-Ghana. He has authored six books and co-authored six other books. He has eighteen articles to his credit. His areas of research are Theology and Spirituality. 